Journal of Engineering and Applied Sciences 14 (23): 8647-8657, 2019

ISSN: 1816-949X

(C) Medwell Journals, 2019

\title{
Effect of Nano-Copper Additives on the Physical Properties of Porous Alumina Ceramics using Graphite Waste as a Pore-Forming Agent
}

\author{
${ }^{1}$ Mohammed Sabah Ali, ${ }^{2}$ Mohanad Aljanabi, ${ }^{3}$ Haider Al-Hamadani and \\ ${ }^{4}$ Azmah Hanim Mohamed Ariff \\ ${ }^{1}$ Department of Biomedical Engineering, Faculty of Engineering, University of Kerbala, Kerbala, Iraq \\ ${ }^{2}$ Department of Electrical Power Techniques Engineering, \\ ${ }^{3}$ Department of Agriculture Machinery Techniques Engineering, Technical College, \\ Al-Mussaib Al-Furat, Al-Awsat Technical University, Najaf, Iraq \\ ${ }^{4}$ Department of Mechanical and Manufacturing Engineering, Faculty of Engineering, \\ Universiti Putra Malaysia, 43400 Serdang, Selangor, Malaysia \\ mohammed.sabah94@yahoo.com
}

\begin{abstract}
Solid state and sacrificial techniques were used to prepare the porous alumina ceramics. The target of the present resesrach is to investigate the effect of $\mathrm{Cu}$ metal addition of nanoscale particle size on the physical properties of porous alumina ceramics using graphite waste as a pore-forming agent. X-Ray Diffraction (XRD), a Field Emission Scanning Electron Microscope (FESEM) and a Transmission and Electron Microscope (TEM) were used to analyse the microstructure and ceramic phases. Different ratios of $\mathrm{Cu}$ metal were added (3, 6,9 and 12 wt.\%) at different ratios of graphite waste. The results of this investigation show that with increasing ratios of $\mathrm{Cu}$ metal, the porosity decreased while the shrinkage and densities increased. Increases in the density and decreases in the porosity of porous alumina ceramics and the formation of the tenorite $(\mathrm{CuO})$ phase due to sintering at high temperature $\left(1600^{\circ} \mathrm{C}\right)$ may lead to improving the strength of porous alumina ceramics. Some potential applications include gas filtration components and as thermal insulation materials.
\end{abstract}

Key words: Porous alumina, graphite waste, nano-copper, physical properties, alumina ceramics, thermal insulation materials

\section{INTRODUCTION}

Porous ceramic materials have been widely used as filters, membranes, sensors, catalytic substrates, thermal insulators (Novais et al., 2014; Shen et al., 2007), gas-burner media, refractory materials, filters for molten metals (Eom and Kim, 2009, 2010), hot gases and others. This is because of their superior properties such as low bulk density, high permeability, high-temperature stability (Jean et al., 2014; Hou et al., 2013), erosion/corrosion resistance and excellent catalytic activity (Chi et al., 2004; Ding et al., 2007; Mohanta et al., 2014; Zhao et al., 2014). Porous alumina ceramics have very many important uses such as in water filters, thermal insulation, hip implants, etc (Mohanta et al., 2014; Liu et al., 2016; Affatato et al., $2015)$. The pores in porous alumina $\left(\mathrm{Al}_{2} \mathrm{O}_{3}\right)$ ceramics can be made by burning out the pore former in a sintering process. There are two kinds of pore-forming agent, i.e., inorganic materials (such as $\mathrm{NH}_{4} \mathrm{HCO}_{3} \mathrm{C}$ powder and others) and organic materials (such as starch, PVA, PVB) (Chi et al., 2004; Alves et al., 1998).
In general, porous ceramics can be classified into three grades according to the pore diameter: micro-pore ceramics in the range of $\mathrm{d}<2 \mathrm{~nm}$, meso-pore ceramics in the range of $50 \mathrm{~nm}>\mathrm{d}>2 \mathrm{~nm}$ and macro-pore ceramics in the range of $\mathrm{d}>50 \mathrm{~nm}$ (Studart et al., 2006; Ohji and Fukushima, 2012). For example, meso and macro-pore ceramics are desired in sensors and catalysis to supply a high surface area and to improve the accessibility of liquids and gases to reactive areas. Small pores in the range of 50-100 nm are desired to provide physical cues that promote the differentiation, proliferation and migration of cells. Large pores $>300-400 \mu \mathrm{m}$ with hierarchical structures are desired in regenerative medicine for implanted scaffold vascularization (Studart et al., 2010). In addition, there are many methods for fabricating porous ceramics such as partial sintering, sacrificial fugitives, replica templates, direct foaming etc (Ohji and Fukushima, 2012).

The selection of the fabrication process plays an important role in controlling the microstructure and the resulting properties of porous ceramics (Mohanta et al.,

Corresponding Author: Mohammed Sabah Ali, Department of Biomedical Engineering, Faculty of Engineering,

University of Kerbala, Kerbala, Iraq, mohammed.sabah94@yahoo.com 
2014; Yin et al., 2009). Among a variety of processes, one of the popular approaches adopted for the fabrication of porous ceramics includes the use of pore forming additives which burn out during sintering leaving porosity in the sample (Chevalier et al., 2008). Recently, there has been a renewed interest in using waste materials. In general, there are two kinds of waste materials, i.e., agricultural waste materials such as rice husk (Mohanta et al., 2014) and kenaf waste (Sengphet et al., 2013) and industrial waste materials such as fly ash (Dong et al., 2010; Sun et al., 2016), paper pulp (Dasgupta and Das, 2002) and glass. These types of waste have been successfully used in the fabrication of porous ceramics (Mohanta et al., 2014). A number of researchers have reported using pure graphite as a pore-forming agent. Piazza et al. (2005) used lamellar graphite as a pore-forming agent to fabricate Porous Lead Zirconate Titanate (PZT) ceramics with uniform porosity. Ding et al. (2007) used graphite as a pore-forming agent to produce mullite-bonded porous silicon carbide by an in-situ reaction bonding technique. The size of the pores derived from the burnout of the graphite depends on the size of the graphite particles. Bai (2010) used graphite as a pore former with the reaction sintering method to prepare porous mullite ceramics from calcined carbonaceous kaolin and $-\mathrm{Al}_{2} \mathrm{O}_{3}$. As for Rahmawati et al. (2014), they used the graphite waste from batteries as an anode material for a $\mathrm{LiFePO}_{4}$ (LFP) battery. Ali et al. (2017a) used graphite waste from a primary battery as a pore-forming agent to produce porous alumina ceramics.

Several researchers have studied the effect of metal additives such as Aluminum (Al), Nickel (Ni), Platinum $(\mathrm{Pt})$ and Copper $(\mathrm{Cu})$ on the mechanical properties of porous ceramics (Li et al., 2010; Wang et al., 2007). Therefore, the main objective of this research is to study the effect of Copper $(\mathrm{Cu})$ additives of nanoscale particle size on the physical properties of alumina porous ceramics such as the porosity level, open porosity, density and linear shrinkage.

\section{MATERIALS AND METHODS}

A commercial Copper $(\mathrm{Cu})$ of nanoscale particle size at $<100 \mathrm{~nm}$ was used as the reinforcement material. The morphology and the size of the nano-copper particles were examined using the FESEM technique (Fig. 1). The density of copper is $7.59 \mathrm{~g} / \mathrm{cm}^{3}$ as determined by the Accupyc II 1340. Commercial Aluminum Oxide $\left(\mathrm{Al}_{2} \mathrm{O}_{3}\right)$ powder $\left(\mathrm{p}=3.94 \mathrm{~g} / \mathrm{cm}^{3}\right)$ with a purity of $99.9 \%$ and particle size of $0.5 \mu \mathrm{m}$ was used as the matrix material.

Commercial sucrose (sugar) was used as a binder $(10-12 \%)$ in the ceramic mixture based on the maximum

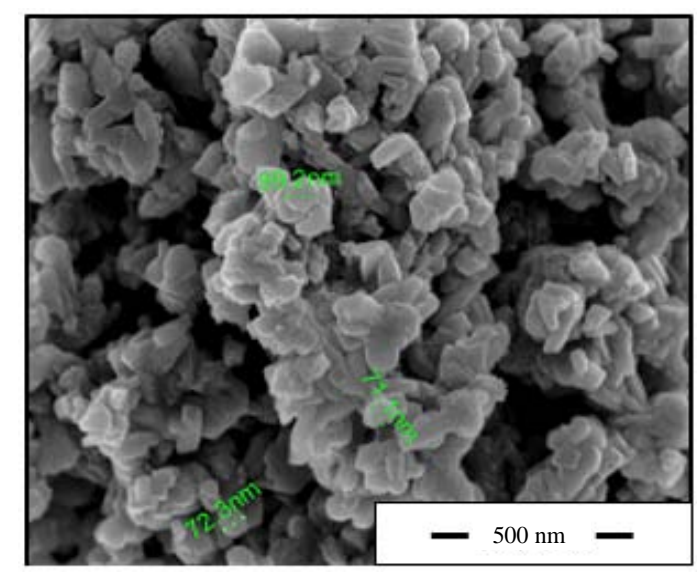

Fig. 1: FESEM image of nano-Cu particles

solubility of sugar in water (distilled water); $60 \mathrm{wt} . \%$ concentration solution was the concentration used in this research. The binder was manually mixed with ceramic powder using an agate mortar for 3-5 min. Meanwhile graphite waste was collected from primary batteries. The graphite rods were cleaned using acetone solvent to remove traces of oil and other wastes from the primary battery. At the start of the procedure, a drying process was carried out in air for $24 \mathrm{~h}$, followed by a drying process for $1 \mathrm{~h}$ in an electric oven at $100^{\circ} \mathrm{C}$. Next, the graphite waste was crushed and ground by an electric grinder (Model RT-02A) with operations at $3000 \mathrm{rpm}$. Finally, the graphite powder was screened to a particle size of $250 \mu \mathrm{m}$. The true density of the graphite waste was determined to be $1.77 \mathrm{~g} / \mathrm{cm}^{3}$ as measured by the Accupyc II 1340.

The ceramic mixture preparation involves two processes. The first step is to mix the nano-Cu metal with $\mathrm{Al}_{2} \mathrm{O}_{3}$ powder. The $\mathrm{Cu}$ powder was added at ratios of 3,6 , 9 and $12 \mathrm{wt} . \%$ to the $\mathrm{Al}_{2} \mathrm{O}_{3}$ powder and mixed manually for $10 \mathrm{~min}$ in an agate mortar. The ceramic mixture was then milled for $3 \mathrm{~h}$ by planetary ball milling $(650 \mathrm{rpm})$ using acetone at $0.5 \mathrm{~mL} / \mathrm{g}$ for the mixture, then dried at $80^{\circ} \mathrm{C}$ for $24 \mathrm{~h}$ in an electric oven. Finally, the mixture was ball-milled for $24 \mathrm{~h}$ to avoid agglomeration. The second step involved mixing the pore agent (graphite waste) with the previous mixture. The graphite waste powder was added at ratios of $10,20,30,40$ and $50 \mathrm{wt} \%$ to the ceramic slurry. Prior to ball milling, the batches were mixed in a mortar for $\sim 5-10 \mathrm{~min}$ and then ball-milled for $3 \mathrm{~h}$ in a plastic container to render the mixture homogenous at a ratio of the weight of alumina balls to the weight of powder of 3:1. Dry mixtures were pressed uniaxially in a circular steel die (diameter $=20 \mathrm{~mm}$ and thickness $=5 \mathrm{~mm}$ ) using an Instron hydraulic press at a pressure of $90 \mathrm{MPa}$. The green compacts were dried in an oven at $110^{\circ} \mathrm{C}$ for $24 \mathrm{~h}$. 

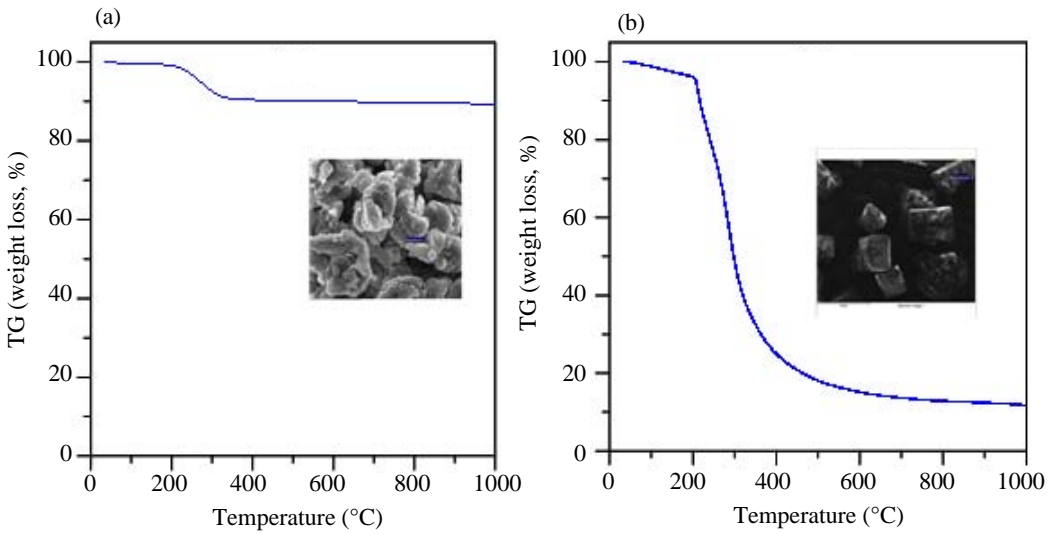

Fig. 2: TGA and FESEM images: a) Graphite waste and b) Sucrose (sugar)

Table 1: Chemical composition of the graphite waste

\begin{tabular}{ll}
\hline Materials & Graphite wastes \\
\hline Density $\left(\mathrm{g} / \mathrm{cm}^{3}\right)$ & 1.77 \\
Elements & Weight $\%$ \\
$\mathrm{C}$ & 95.72 \\
$\mathrm{O}_{2}$ & 3.46 \\
$\mathrm{Si}$ & 0.34 \\
$\mathrm{P}$ & - \\
$\mathrm{S}$ & 0.36 \\
$\mathrm{~K}$ & - \\
$\mathrm{AL}$ & 0.12 \\
$\mathrm{Mg}$ & - \\
$\mathrm{Ca}$ & - \\
\hline
\end{tabular}

The organic burnout of the dried samples was carried out in an ambient atmosphere in an electrically heated, programmable furnace. The rate of heating was $1.5^{\circ} \mathrm{C} / \mathrm{min}$ for each increment in the temperature. According to the Thermo Gravimetric Analysis (TGA) of sucrose and graphite waste (Fig. 2), the samples were sintered at 200 , 300,500 and $900^{\circ} \mathrm{C}$ for a soaking time period of $1 \mathrm{~h}$ in an electric furnace. The rates of heating and cooling were set at $1.5^{\circ} \mathrm{C} / \mathrm{min}$ for the removal of graphite waste and sucrose. After that, the ceramic samples were sintered at $1600^{\circ} \mathrm{C}$ for a soaking time period of $2 \mathrm{~h}$ and the rates of heating and cooling were set at $5^{\circ} \mathrm{C} / \mathrm{min}$. The findings revealed that after sintering, all the samples with different ratios of graphite waste and binder (sucrose) had a uniform shape without any cracks.

The chemical composition and density for graphite waste ash were measured by an EDX and gas pycnometer (Accupyc II 1340) machines. Table 1 shows the chemical composition of the graphite waste used.

Based on the TGA data of graphite waste and sucrose, the sintering temperature of porous alumina ceramics was selected in order to perform the sintering process (Dittmann and Willenbacher, 2014; Eom et al., 2013). It is necessary to achieve a controlled burn out in the process for the graphite waste and sucrose in order to obtain defect-free samples (Ighodaro et al., 2012).
Characterisation of ceramic samples: In this study, the phase compositions of the porous ceramics were determined using an X-ray diffractometer (PANalytical (Philips) X'pert ProPW3050/60) with $\mathrm{Cu}$ radiation (wavelength $=1.54060 \AA$ ) that had been set at $40 \mathrm{~mA}$ and $40 \mathrm{kV}$ over the $2 \cdot$ angles range from $20-80^{\circ}$ to identify the developed crystalline and amorphous phases using $\mathrm{X}$-pert Software. The ceramic phases for each sample were compared with some standard references in the X-pert software.

The theoretical density (true) of Alumina $\left(\mathrm{Al}_{2} \mathrm{O}_{3}\right)$ $\left(3.94 \mathrm{~g} / \mathrm{cm}^{3}\right)$ was used as a reference and measured by the Accupyc II 1340. The density and overall porosity of the sintered samples were determined by the water immersion method based on the Archimede's principle as specified in ASTM C20-00 using the following Eq. 1-3:

$$
\begin{gathered}
P_{\text {overall }}=\left(1-\frac{\rho}{\rho \text { theoritical }}\right) \times 100 \\
\rho=\frac{M_{\text {dry }} \times \rho_{\text {water }}}{M_{\text {wet }}-M_{\text {suspended }}+M_{\text {wire }}} \\
P_{\text {open }}=\frac{M_{\text {wet }}-M_{\text {dry }}}{M_{\text {wet }}-M_{\text {suspended }}+M_{\text {wire }}}
\end{gathered}
$$

Where:

$\mathrm{M}_{\mathrm{dry}} \quad=$ The dry mass of the sample

$\mathrm{M}_{\text {suspended }}=$ The mass of the sample suspended in distilled water

$\mathrm{M}_{\text {wet }} \quad=$ The mass of the sample after soaking in water

$\mathrm{M}_{\text {wire }} \quad=$ The mass of the suspending system

$\mathrm{P}_{\text {overall }}=$ The volume fraction of the overall porosity (vol.\%) of the sample ( $\mathrm{Hu}$ et al., 2012; Menchavez and Intong, 2010; Norkhairunnisa and Matori, 2016)

$\mathrm{P}_{\text {open }}=$ The volume fraction of the open porosity of the sample (Hu et al., 2012; Ali et al., 2017b) 
The microstructure and the chemical composition of the porous ceramics were examined using a Field-Emission Scanning Electron Microscope (FESEM) and EDX (SE-440). In this process, all the porous alumina ceramic samples were ground and polished, then heated in an electric furnace at a temperature of $1450^{\circ} \mathrm{C}$ (below the sintering temperature by $150^{\circ} \mathrm{C}$ ) for around $15-20 \mathrm{~min}$. The heating and cooling rate were $10^{\circ} \mathrm{C}$. Due to heating the ceramic material to a temperature below the sintering temperature for a short time, the grain boundaries will seek a lower energy level, hence, becoming rounder. They can then be detected using an electron or optical microscope technique (Cook et al., 1995). This method is called thermal etching. After that, the samples are coated with gold using a spin coating machine. After the sample has been coated, it is transferred on a specific sample holder. The sample is inserted through an exchange chamber into the high vacuum part of the microscope and anchored on a movable stage. Image-J software was used to measure the open pore distribution of the porous alumina ceramics (Ali et al., 2017c). After obtaining a FESEM image with a certain magnification, the relation:

$$
\mathrm{d}=1.56 \frac{\mathrm{L}}{\mathrm{MN}}
$$

Where:

$\mathrm{N}=$ The No. of grain boundary intercepts by the line

$\mathrm{M}=$ The magnification of the image

$\mathrm{L}=$ The random line (Ramakrishna et al., 2014) was used to determine the average pore size

\section{RESULTS AND DISCUSSION}

Table 2 shows the graphite waste ratio, the density for the green and sintered samples, the overall porosity, the open porosity and the shrinkage for porous alumina ceramics with $\mathrm{Cu}$ metal of nanoscale particle size.

Overall porosity-porous alumina ceramics: Figure 3 presents the variation of porosity with Copper $(\mathrm{Cu})$ ratios using different ratios of graphite waste. By increasing the ratio of Copper $(\mathrm{Cu})$, the porosity decreases which leads to an improvement in the mechanical properties. Also, the ratio of the porosity starts to increase at $12 \mathrm{wt} . \% \mathrm{Cu}$ for all ratios of pore agent. This increase in the porosity may be attributed to the increasing pore agent ratio and the molten copper phase is not enough to reduce the porosity. In general, it can be seen in Fig. 3 that with increasing pore agent ratio (graphite waste) the porosity increases for different ratios of Copper $(\mathrm{Cu})$.

Sintered density of porous alumina ceramics: A significant increase in the sintered density was observed in the porous alumina ceramic samples sintered at $1600^{\circ} \mathrm{C}$ for $2 \mathrm{~h}$, reinforced with $\mathrm{Cu}$ at the nanoscale as shown in Fig. 4. As for the sintered density of the porous alumina ceramics, this increased because the high density of copper and the low porosity is due to pore filling by the $\mathrm{Cu}$ metal. The sintered densities of the porous alumina ceramics reinforced by $\mathrm{Cu}$ metal decrease at the ratio

\begin{tabular}{|c|c|c|c|c|c|c|}
\hline $\begin{array}{l}\text { Graphite waste } \\
\text { content (wt.\%)(g) }\end{array}$ & $\begin{array}{l}\text { Alumina }\left(\mathrm{Al}_{2} \mathrm{O}_{3}\right)+ \\
\text { Cu ratio (wt. \%) (g) }\end{array}$ & $\begin{array}{c}\text { Overall porosity } \\
\text { (vol\%) }\end{array}$ & $\begin{array}{c}\text { Open porosity } \\
\text { (vol\%) }\end{array}$ & $\begin{array}{c}\text { Green density } \\
\left(\mathrm{g} / \mathrm{cm}^{3}\right)\end{array}$ & $\begin{array}{l}\text { Sintered density } \\
\left(\mathrm{g} / \mathrm{cm}^{3}\right)\end{array}$ & $\begin{array}{c}\text { Linear } \\
\text { shrinkage }(\%)\end{array}$ \\
\hline 10 & $90 \% \mathrm{Al}_{2} \mathrm{O}_{3}$ & $37.27 \pm 1.25$ & $18.44 \pm 0.82$ & $1.81 \pm 0.005$ & $2.47 \pm 0.012$ & $14.99 \pm 1.27$ \\
\hline 10 & $\left(87 \% \mathrm{Al}_{2} \mathrm{O}_{3}+3 \% \mathrm{Cu}\right)$ & $26.94 \pm 0.84$ & $13.52 \pm 0.76$ & $1.93 \pm 0.007$ & $2.88 \pm 0.023$ & $20.61 \pm 0.87$ \\
\hline 10 & $\left(84 \% \mathrm{Al}_{2} \mathrm{O}_{3}+6 \% \mathrm{Cu}\right)$ & $24.80 \pm 0.67$ & $12.82 \pm 0.49$ & $1.95 \pm 0.009$ & $2.96 \pm 0.013$ & $20.57 \pm 0.56$ \\
\hline 10 & $\left(81 \% \mathrm{Al}_{2} \mathrm{O}_{3}+9 \% \mathrm{Cu}\right)$ & $24.71 \pm 0.32$ & $11.81 \pm 0.35$ & $1.99 \pm 0.006$ & $2.96 \pm 0.011$ & $19.56 \pm 0.67$ \\
\hline 10 & $\left(78 \% \mathrm{Al}_{2} \mathrm{O}_{3}+12 \% \mathrm{Cu}\right)$ & $24.00 \pm 0.21$ & $10.41 \pm 0.38$ & $2.02 \pm 0.008$ & $2.99 \pm 0.009$ & $19.22 \pm 0.53$ \\
\hline 20 & $80 \% \mathrm{Al}_{2} \mathrm{O}_{3}$ & $45.71 \pm 2.11$ & $24.87 \pm 1.11$ & $1.82 \pm 0.004$ & $2.14 \pm 0.014$ & $14.72 \pm 0.69$ \\
\hline 20 & $\left(77 \% \mathrm{Al}_{2} \mathrm{O}_{3}+3 \% \mathrm{Cu}\right)$ & $34.03 \pm 0.81$ & $17.94 \pm 0.98$ & $1.88 \pm 0.017$ & $2.60 \pm 0.025$ & $21.45 \pm 0.86$ \\
\hline 20 & $\left(74 \% \mathrm{Al}_{2} \mathrm{O}_{3}+6 \% \mathrm{Cu}\right)$ & $33.44 \pm 0.76$ & $16.80 \pm 0.54$ & $1.91 \pm 0.018$ & $2.62 \pm 0.006$ & $21.22 \pm 0.63$ \\
\hline 20 & $\left(71 \% \mathrm{Al}_{2} \mathrm{O}_{3}+9 \% \mathrm{Cu}\right)$ & $31.07 \pm 0.45$ & $16.30 \pm 0.33$ & $1.96 \pm 0.009$ & $2.71 \pm 0.007$ & $20.93 \pm 0.52$ \\
\hline 20 & $\left(68 \% \mathrm{Al}_{2} \mathrm{O}_{3}+12 \% \mathrm{Cu}\right)$ & $28.95 \pm 0.78$ & $15.64 \pm 0.23$ & $1.99 \pm 0.011$ & $2.80 \pm 0.018$ & $20.49 \pm 0.51$ \\
\hline 30 & $70 \% \mathrm{Al}_{2} \mathrm{O}_{3}$ & $46.19 \pm 1.56$ & $28.23 \pm 0.93$ & $1.78 \pm 0.013$ & $2.12 \pm 0.012$ & $18.42 \pm 0.77$ \\
\hline 30 & $\left(67 \% \mathrm{Al}_{2} \mathrm{O}_{3}+3 \% \mathrm{Cu}\right)$ & $37.24 \pm 0.96$ & $20.04 \pm 0.78$ & $1.87 \pm 0.016$ & $2.47 \pm 0.028$ & $20.49 \pm 0.83$ \\
\hline 30 & $\left(64 \% \mathrm{Al}_{2} \mathrm{O}_{3}+6 \% \mathrm{Cu}\right)$ & $31.56 \pm 0.87$ & $17.44 \pm 0.68$ & $1.92 \pm 0.008$ & $2.70 \pm 0.009$ & $22.05 \pm 0.76$ \\
\hline 30 & $\left(61 \% \mathrm{Al}_{2} \mathrm{O}_{3}+9 \% \mathrm{Cu}\right)$ & $33.02 \pm 0.76$ & $18.47 \pm 0.37$ & $1.94 \pm 0.014$ & $2.64 \pm 0.024$ & $22.45 \pm 0.56$ \\
\hline 30 & $\left(58 \% \mathrm{Al}_{2} \mathrm{O}_{3}+12 \% \mathrm{Cu}\right)$ & $34.37 \pm 0.35$ & $19.56 \pm 0.22$ & $1.90 \pm 0.008$ & $2.58 \pm 0.016$ & $22.42 \pm 0.71$ \\
\hline 40 & $60 \% \mathrm{Al}_{2} \mathrm{O}_{3}$ & $53.60 \pm 0.98$ & $39.15 \pm 1.22$ & $1.74 \pm 0.006$ & $1.83 \pm 0.008$ & $20.50 \pm 0.88$ \\
\hline 40 & $\left(57 \% \mathrm{Al}_{2} \mathrm{O}_{3}+3 \% \mathrm{Cu}\right)$ & $44.26 \pm 1.01$ & $30.52 \pm 0.83$ & $1.85 \pm 0.006$ & $2.20 \pm 0.011$ & $22.38 \pm 0.53$ \\
\hline 40 & $\left(54 \% \mathrm{Al}_{2} \mathrm{O}_{3}+6 \% \mathrm{Cu}\right)$ & $40.07 \pm 0.91$ & $26.08 \pm 0.78$ & $1.86 \pm 0.019$ & $2.36 \pm 0.015$ & $24.14 \pm 0.61$ \\
\hline 40 & $\left(51 \% \mathrm{Al}_{2} \mathrm{O}_{3}+9 \% \mathrm{Cu}\right)$ & $37.31 \pm 0.82$ & $24.07 \pm 0.34$ & $1.90 \pm 0.013$ & $2.47 \pm 0.017$ & $25.11 \pm 0.55$ \\
\hline 40 & $\left(48 \% \mathrm{Al}_{2} \mathrm{O}_{3}+12 \% \mathrm{Cu}\right)$ & $38.09 \pm 0.56$ & $24.83 \pm 0.24$ & $1.89 \pm 0.008$ & $2.44 \pm 0.006$ & $25.39 \pm 0.50$ \\
\hline 50 & $50 \% \mathrm{Al}_{2} \mathrm{O}_{3}$ & $61.08 \pm 1.11$ & $53.94 \pm 0.87$ & $1.73 \pm 0.008$ & $1.53 \pm 0.009$ & $21.73 \pm 0.76$ \\
\hline 50 & $\left(47 \% \mathrm{Al}_{2} \mathrm{O}_{3}+3 \% \mathrm{Cu}\right)$ & $51.43 \pm 1.34$ & $38.20 \pm 1.04$ & $1.74 \pm 0.007$ & $1.91 \pm 0.005$ & $24.14 \pm 0.87$ \\
\hline 50 & $\left(44 \% \mathrm{Al}_{2} \mathrm{O}_{3}+6 \% \mathrm{Cu}\right)$ & $44.93 \pm 0.87$ & $31.48 \pm 0.69$ & $1.85 \pm 0.019$ & $2.17 \pm 0.011$ & $26.67 \pm 0.64$ \\
\hline 50 & $\left(41 \% \mathrm{Al}_{2} \mathrm{O}_{3}+9 \% \mathrm{Cu}\right)$ & $41.19 \pm 0.76$ & $27.32 \pm 0.99$ & $1.87 \pm 0.013$ & $2.32 \pm 0.005$ & $28.697 \pm 0.71$ \\
\hline 50 & $\left(38 \% \mathrm{Al}_{2} \mathrm{O}_{3}+12 \% \mathrm{Cu}\right)$ & $41.995 \pm 0.45$ & $30.42 \pm 0.65$ & $1.84 \pm 0.012$ & $2.28 \pm 0.006$ & $27.59 \pm 0.61$ \\
\hline
\end{tabular}




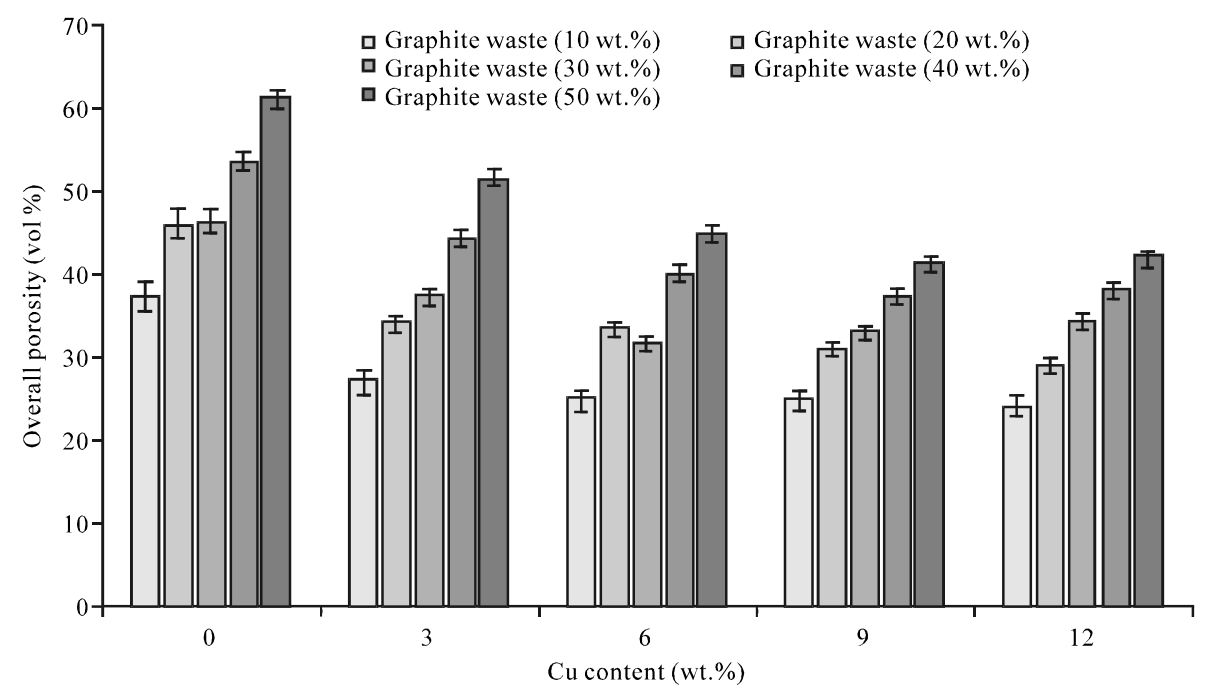

Fig. 3: Variation of the porosity of porous alumina ceramic samples sintered at $1600^{\circ} \mathrm{C}$ for $2 \mathrm{~h}$ with copper content for different ratios of graphite waste

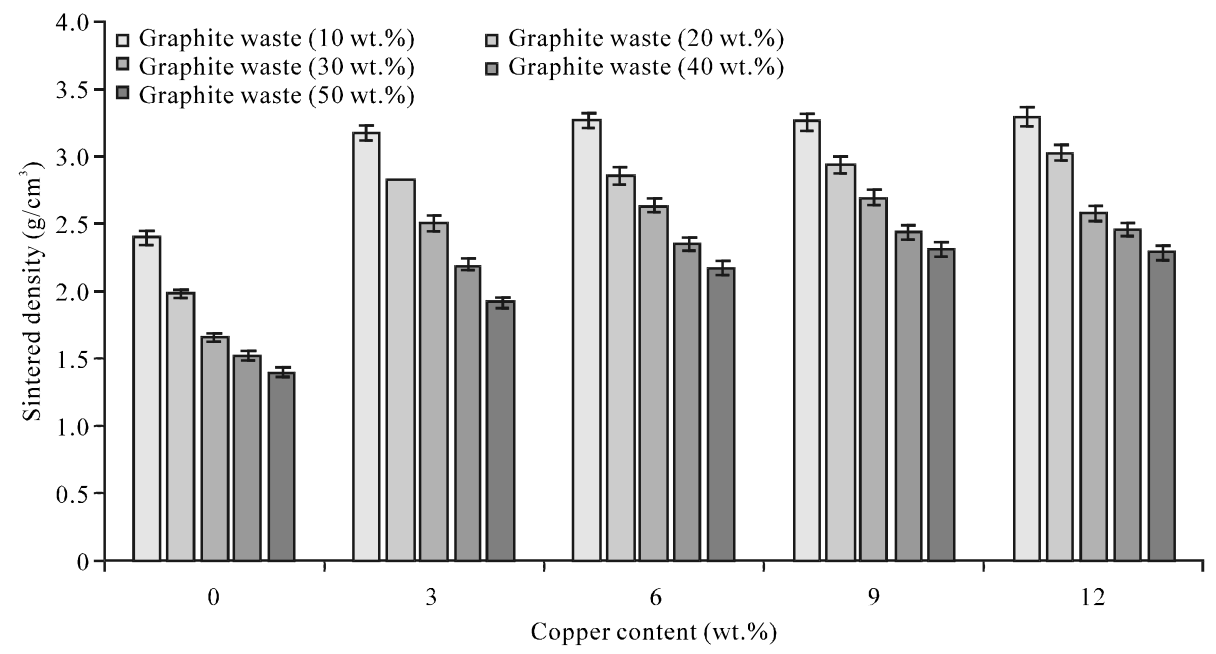

Fig. 4: Variation of the sintered densities of the porous alumina ceramics, sintered at $1600^{\circ} \mathrm{C}$ for $2 \mathrm{~h}$ with the ratio of copper content for different ratios of graphite waste

of 12 wt. $\% \mathrm{Cu}$. This decreasing density is due to the increase in the pore agent ratio and hence, the molten copper phase is not enough to reduce the porosity.

Green density of the porous alumina ceramics: An increase in the green density was observed in the green body reinforced with $\mathrm{Cu}$ at the nanoscale as shown in Fig. 5. The increase in the green density is due to the addition of copper particles which have a density $\left(7.59 \mathrm{~g} / \mathrm{cm}^{3}\right)$ higher than the density of alumina $\left(3.94 \mathrm{~g} / \mathrm{cm}^{3}\right)$ and graphite waste $\left(1.77 \mathrm{~g} / \mathrm{cm}^{3}\right)$ materials.

Linear shrinkage of porous alumina ceramics: The shrinkage of porous alumina ceramic samples sintered at $1600^{\circ} \mathrm{C}$ for $2 \mathrm{~h}$ has a notable variation with increasing ratio of $\mathrm{Cu}$ (Fig. 6). With increasing $\mathrm{Cu}$ content ratio, the shrinkage increases. This could be attributed to the nanoparticle size of the copper particles. This means that after mixing the nano-sized copper particles, they will occupy less space than if they were micron-sized, leading to an increase in the shrinkage of the ceramic body and also, to the ductile feature of the copper particles, thus, decreasing the dimensions of the ceramic samples after pressing. Through sintering at high temperature, the $\mathrm{Cu}$ metal melts and fills the pores which leads to increasing shrinkage. In addition, the porous alumina samples have a shrinkage that increases with the increase of the graphite waste ratio for all ratios of the $\mathrm{Cu}$ metal. It seems 


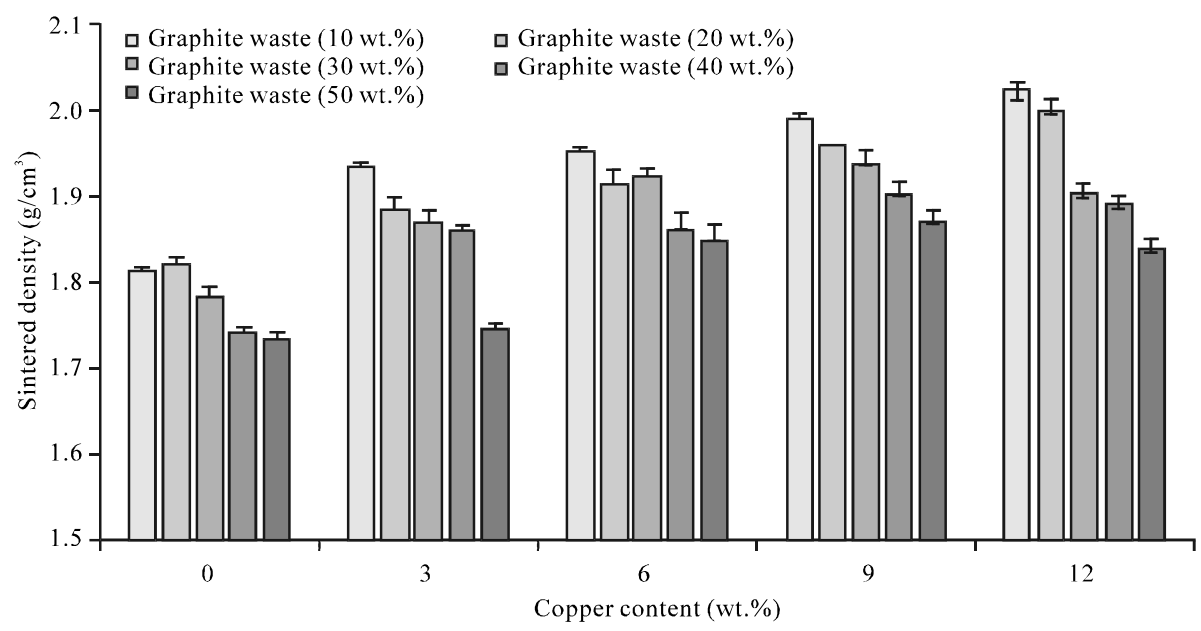

Fig. 5: Variation of the green densities of porous alumina ceramic, sintered at $1600^{\circ} \mathrm{C}$ for $2 \mathrm{~h}$ with the ratio of copper content for different ratios of graphite waste

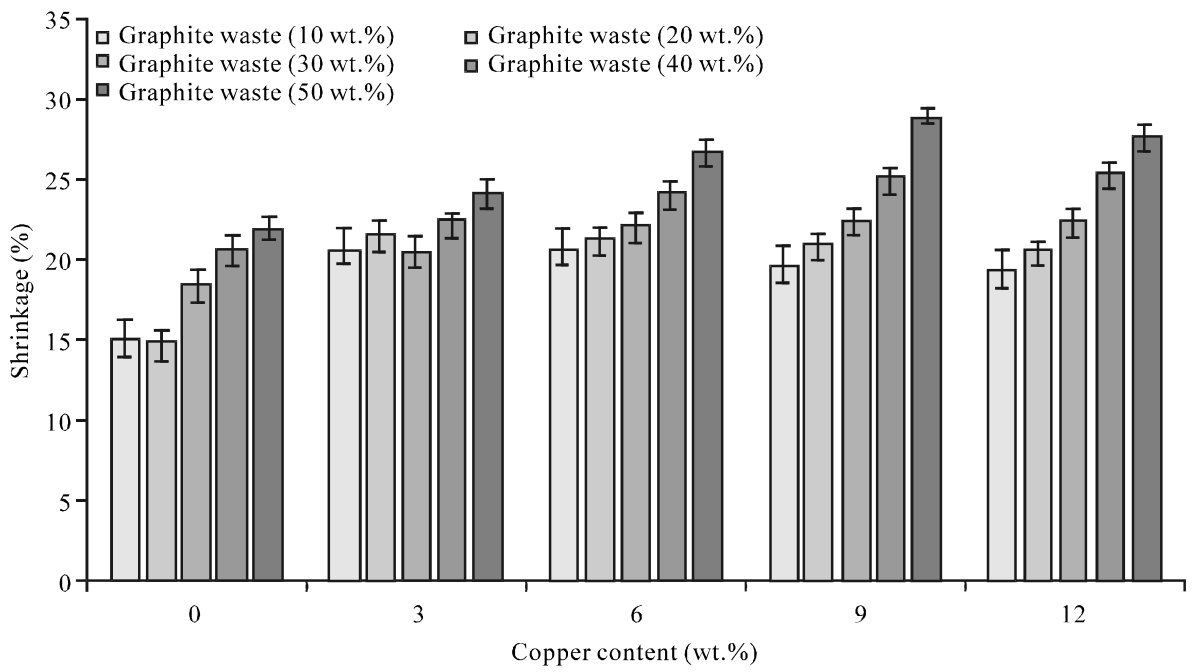

Fig. 6: The variation in shrinkage of porous alumina ceramic samples, sintered at $1600^{\circ} \mathrm{C}$ for $2 \mathrm{~h}$ with the ratio of copper content for different ratios of graphite waste

possible that the increasing shrinkage is due to the porosity, the pore size and the binder ratio $(10-12 \%)$ (Feng et al., 2013).

Microstructure of the porous alumina ceramics: In general with increasing graphite waste ratios (10-50 wt.\%) for all ratios of $\mathrm{Cu}$, the porosity increases as shown in Fig. 7a-c. This increasing porosity for all ratios is due to the burnout of the graphite waste and the binder (sucrose). While at the same time with increasing ratios of Copper $(\mathrm{Cu})$, the porosity decreases which may lead to an improvement in the mechanical properties of the alumina porous ceramics (Norkhairunnisa and Matori, 2016; Ali et al., 2017b).
Figure 7a-c show the irregular shaped pores which may be attributed to the shape of the graphite waste particles after burning at a high sintering temperature. Sintering at high temperature bears a positive impact as the necks are well-developed, leading to improvements in the mechanical properties.

For an explanation of the behaviour of the $\mathrm{Cu}$ metal and the pore agent ratio (graphite waste) in porous alumina ceramic samples, there are two stages in the processing mechanism. The first stage is the removal of the graphite waste, according to the TGA analysis. The removal of the graphite waste from green body takes place at a temperature below the melting point of the Cu metal. In this case, the alumina matrix has a porosity with the $\mathrm{Cu}$ 


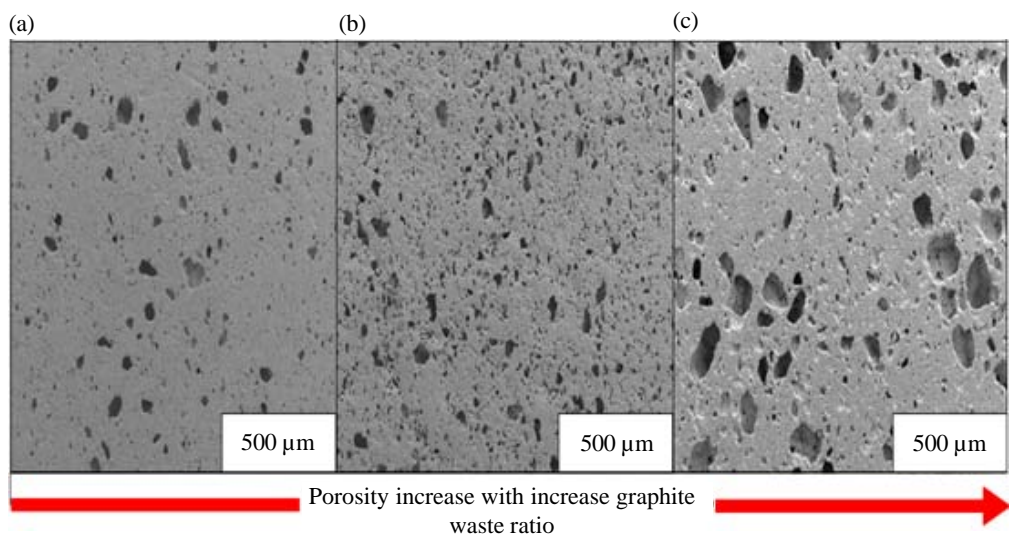

Fig. 7: The irregular shape of the pores and the necks in the porous alumina ceramic body of porous alumina ceramic samples sintered at $1600^{\circ} \mathrm{C}$ for $2 \mathrm{~h}$ for different ratios of: a) $10 \%$ graphite waste +12 copper (wt. $\%$ ); b) 30 graphite waste +12 copper (wt.\%) and c) 50 graphite waste+12 copper (wt.\%)

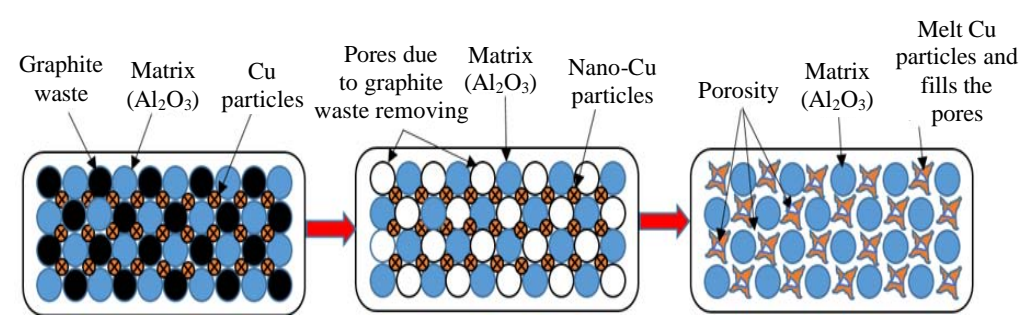

Fig. 8: a) Green body of alumina ceramic composite at room temperature; b) Removal of the pore agent (graphite waste) according to the TGA and c) Melt $\mathrm{Cu}$ particles to fill the pores of porous alumina samples which leads to reduction of porosity (Norkhairunnisa and Matori, 2016)

particles (Fig. 8b). The second stage is the melting of the $\mathrm{Cu}$ metal. When the sintering temperature is at $1600^{\circ} \mathrm{C}$, the main focus is the melting of the $\mathrm{Cu}$ metal. This stage leads to an improvement in the mechanical properties as the $\mathrm{Cu}$ metal phase is homogenous. At this stage, the molten $\mathrm{Cu}$ metal fills the pores to reduce the porosity. With an increase in the ratio of the $\mathrm{Cu}$ metal, the molten $\mathrm{Cu}$ is sufficient to fill the porous alumina body (Fig. 8c). As a result, the pores accumulate between the grains and they become wet in the liquid phase of the Cu metal (Shaw, 1993). Also, capillarity drives the liquid phase of the $\mathrm{Cu}$ metal to fill the smaller pores. As the smaller pores are filled, the number of pores and the porosity decrease while the mean pore size increases. This leads to an improvement in the mechanical properties (Norkhairunnisa and Matori, 2016; Ali et al., 2017d).

Open pore size distribution of porous alumina ceramics: Figure 9 illustrates the pore size (open pore) distribution with the ratio of pores for the porous alumina samples with a graphite waste ratio of 10,30 and $50 \mathrm{wt} . \%$ reinforced with $\mathrm{Cu}$ metal in nanoscale particles. According to this graph, the different pore size is attributed to the particle size distribution of the graphite waste powder, the ratio of the $\mathrm{Cu}$ metal and the ratio of the binder. The distribution of the pore size is closely affected by the ratios of the graphite waste and the $\mathrm{Cu}$ metal ratios. For example at the ratios of $10 \mathrm{wt} . \%$ graphite waste $+12 \mathrm{wt} . \%$ $\mathrm{Cu}$ metal, $30 \mathrm{wt} . \%$ graphite waste $+12 \mathrm{wt} . \% \mathrm{Cu}$ metal and 50 wt. $\%$ graphite waste +12 wt. $\% \mathrm{Cu}$ metal, the average pore sizes were $62.52,65.23$ and $75.28 \mu \mathrm{m}$, respectively. All the samples presented unimodal pore size distribution for all the ratios.

Phase formation of porous alumina ceramics: Figure 10 presents the XRD pattern of the porous alumina samples at ratios of 10,30 and $50 \mathrm{wt} . \%$ graphite waste after sintering at $1600^{\circ} \mathrm{C}$ for 2 . It was noted that with increasing ratios of graphite waste and sintering at high temperature, the phases detected in the samples of the porous alumina with graphite waste included corundum $\left(\mathrm{Al}_{2} \mathrm{O}_{3}\right)$ and tenorite $(\mathrm{CuO})$. The corundum $\left(\mathrm{Al}_{2} \mathrm{O}_{3}\right)$ and tenorite $(\mathrm{CuO})$ (JCPDS file No.: 00-001-1117) phases were matched with their JCPDS file No. no graphite phase was detected, 

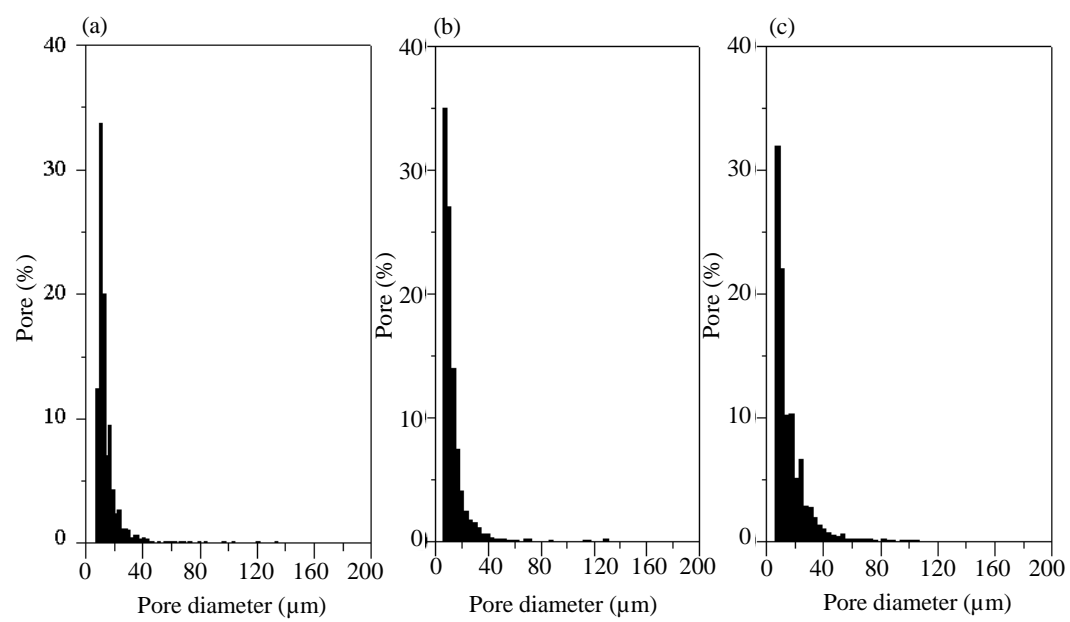

Fig. 9: Distribution of open pore size for the samples of porous alumina ceramic with $\mathrm{Cu}$ metal, sintered at $1600^{\circ} \mathrm{C}$ for $2 \mathrm{~h}$ with different ratios of graphite waste: a) $10 \%$ graphite waste +12 copper (wt.\%); b) 30 graphite waste +12 copper (wt.\%) and c) 50 graphite waste+12 copper (wt.\%)

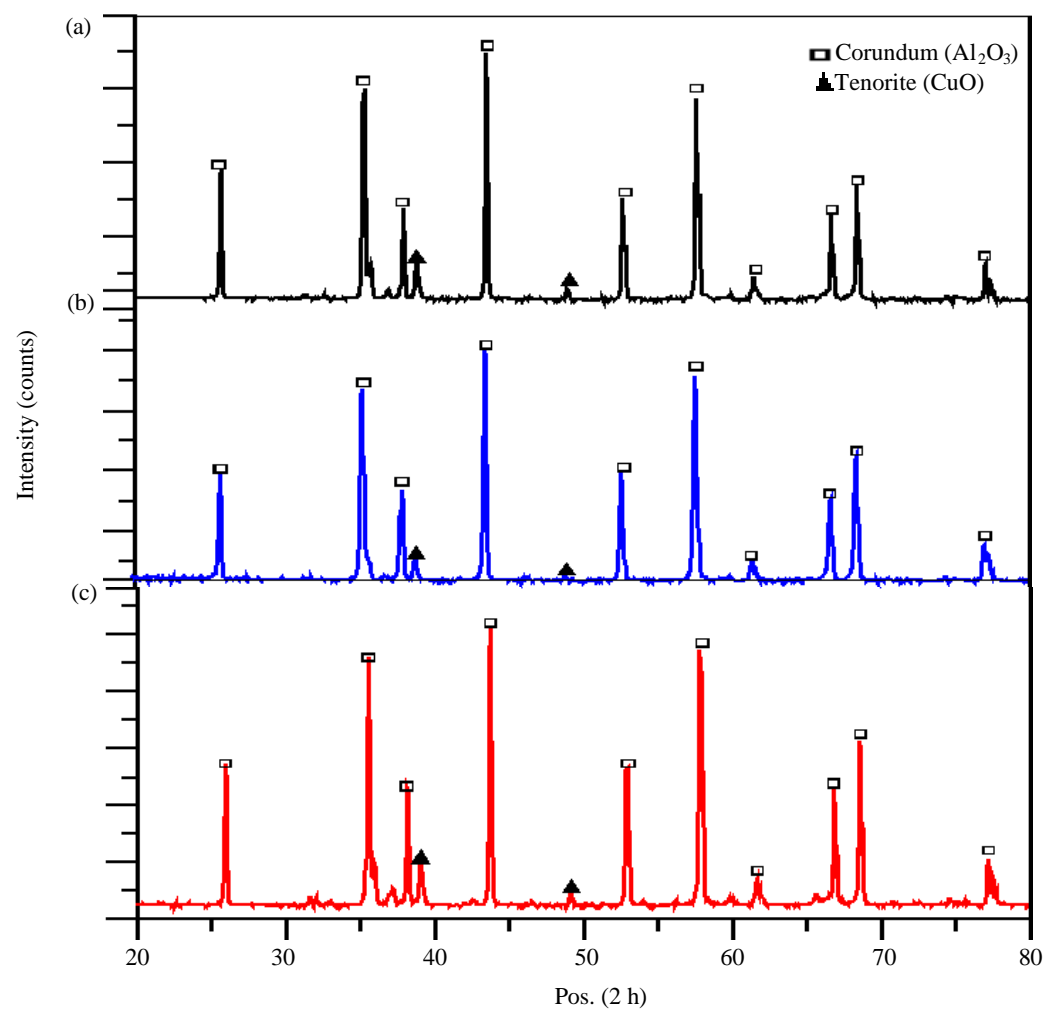

Fig. 10: XRD patterns of porous alumina ceramics samples, sintered at $1600^{\circ} \mathrm{C}$ for $2 \mathrm{~h}$ with different ratios of graphite waste: a) 50 graphite waste +12 copper (wt.\%); b) 30\% graphite waste +12 copper (wt.\%) and c) $10 \%$ graphite waste+12 copper (wt.\%)

showing the total removal of the graphite waste from the ceramic body during the sintering process. The presence of the tenorite $(\mathrm{CuO})$ phase is an important feature after adding $\mathrm{Cu}$ metal to porous alumina ceramics as mentioned in the latest study by MubarakAli et al. (2015). Tenorite nanoparticles are an ideal candidate in 

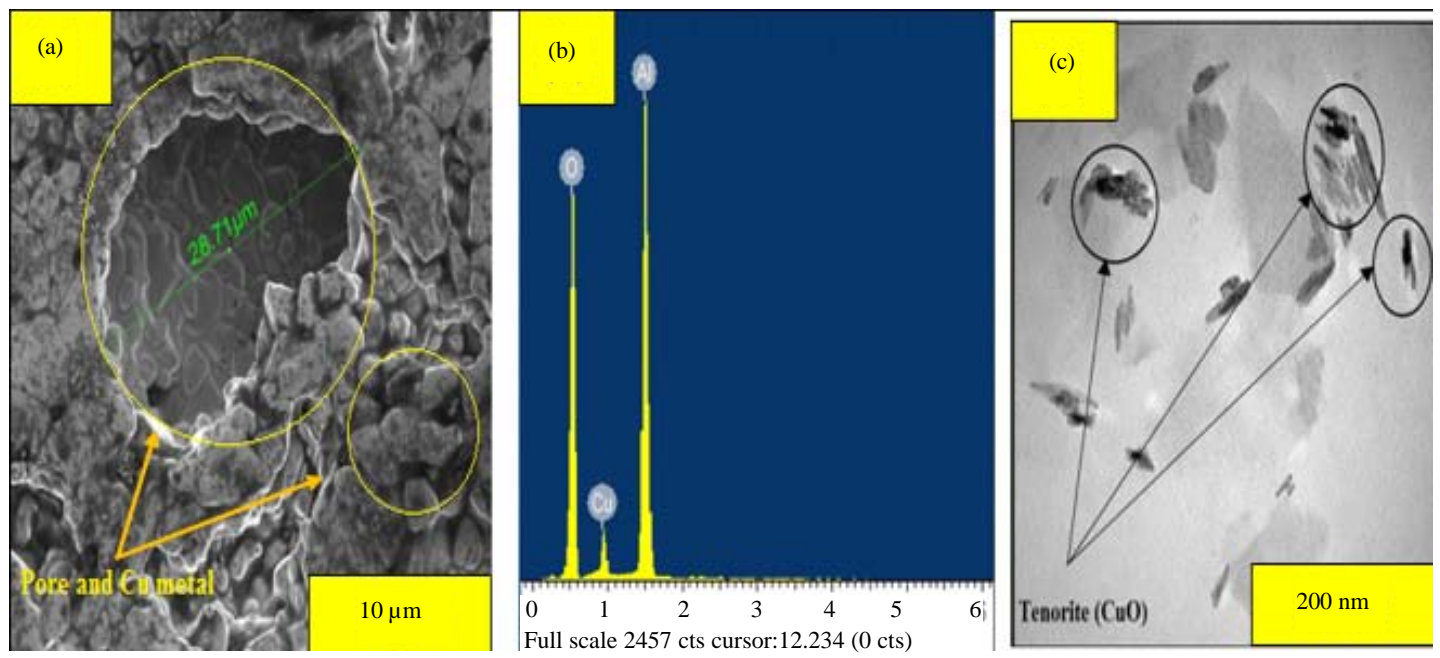

Fig. 11:a) FESEM; b) EDX and c) TEM of porous alumina ceramics with nano-copper using graphite waste as pore-forming agent

medical applications such as medical implants which means that presence of $\mathrm{CuO}$ in porous ceramics is biocompatible.

\section{Transmission Electron Microscopy (TEM), FESEM and} EDX: Figure 11 shows the TEM, FESEM images and EDX of porous alumina ceramics with nano-copper particles using graphite waste as a pore forming agent. Tenorite $(\mathrm{CuO})$ which has a black colour has been discovered by the XRD test and the corundum $\left(\mathrm{Al}_{2} \mathrm{O}_{3}\right)$ phase can also be seen. In this case, after the $\mathrm{Cu}$ melts during sintering at high temperature, this molten $\mathrm{Cu}$ fill the pores as shown in Fig. 11a and reacts with $\mathrm{O}_{2}$ to produce $\mathrm{CuO}$ which also leads to agglomeration in the grain boundary of the $\mathrm{Al}_{2} \mathrm{O}_{3}$. Filling the pores (porosity decrease) and the presence of $\mathrm{CuO}$ result in an improvement in the mechanical properties of porous alumina ceramics (Ali et al., 2017b, e). The molten $\mathrm{Cu}$ starts to fill the pores of the matrix at an increasing ratio throughout the porous alumina body. After that the tenorite phase appears due to sintering at high temperature $\left(1600^{\circ} \mathrm{C}\right)$ for $2 \mathrm{~h}$ in air. In other words, assuming that the melting of copper happens first, thus, leading to filling the pores and then because the sintering duration is $2 \mathrm{~h}$, the tenorite phase begins to appear. To clarify the phase chemical composition of porous alumina ceramics, EDX analysis was conducted on the selected area of the porous alumina ceramics (Lu et al., 2000).

\section{CONCLUSION}

This study was designed to investigate the effect of $\mathrm{Cu}$ metal at the nanoscale level and the pore agent ratio on the physical properties of porous alumina ceramics. The results of this research have shown that $\mathrm{Cu}$ metal additives have significant effects on the physical properties of porous alumina ceramics such as the porosity level, microstructure, shrinkage and density (green and sintered). Decreasing the porosity and increasing the sintered density may lead to improvements in the strength of porous alumina ceramics. Hot gas filters, molten metal filters and membranes are potential applications of the study's results.

\section{ACKNOWLEDGEMENT}

The financial support provided by Universiti Putra Malaysia is much appreciated. Also, the researchers would like to thank the Iraqi Government/Ministry of Higher Education and Scientific Research for the scholarship provided.

\section{REFERENCES}

Affatato, S., A. Ruggiero and M. Merola, 2015. Advanced biomaterials in hip joint arthroplasty: A review on polymer and ceramics composites as alternative bearings. Compos. Part B. Eng., 83: 276-283.

Ali, M.S., A.H.M. Ariff, C.N.A. Jaafar, S.M. Tahir and N. Mazlan et al., 2017b. Factors Affecting the Porosity and Mechanical Properties of Porous Ceramic Composite Materials. In: Reference Module in Materials Science and Materials Engineering, Hashmi, S. (Ed.). Elsevier,? Amsterdam, Netherlands, ISBN: 978-0-12-803581-8, pp: 1-54. 
Ali, M.S., M.A. Azmah Hanim, S.M. Tahir, C.N.A. Jaafar and N. Mazlan et al., 2017c. Effect of cu metal of nanoscale particle size on the porosity and mechanical properties of porous Alumina ceramics using yeast as a pore agent. Res. J. Appl. Sci. Eng. Technol., 14: 187-195.

Ali, M.S., M.A. Azmah Hanim, S.M. Tahir, C.N.A. Jaafar and N. Mazlan et al., 2017a. The effect of commercial rice husk ash additives on the porosity, mechanical properties and microstructure of Alumina ceramics. Adv. Mater. Sci. Eng., 2017: 1-10.

Ali, M.S., M.A. Hanim, S.M. Tahir, C.N.A. Jaafar and M. Norkhairunnisa et al., 2017e. The effect of nano-copper additives on the porosity, mechanical properties and microstructure of alumina ceramics using commercial rice husk ash as a pore former. J. Aust. Ceram. Soc., 53: 963-974.

Ali, M.S., M.A.A. Hanim, S.M. Tahir, C.N.A. Jaafar and M. Norkhairunnisa et al., 2017d. Preparation and characterization of porous alumina ceramics using different pore agents. J. Ceram. Soc. Jpn., 125: 402-412.

Alves, H.M., G. Tari, A.T. Fonseca and J.M.F. Ferreira, 1998. Processing of porous cordierite bodies by starch consolidation. Mater. Res. Bull., 33: 1439-1448.

Bai, J., 2010. Fabrication and properties of porous mullite ceramics from calcined carbonaceous kaolin and a- $\mathrm{Al}_{2} \mathrm{O}_{3}$. Ceram. Intl., 36: 673-678.

Chevalier, E., D. Chulia, C. Pouget and M. Viana, 2008. Fabrication of porous substrates: A review of processes using pore forming agents in the biomaterial field. J. Pharm. Sci., 97: 1135-1154.

Chi, W., D. Jiang, Z. Huang and S. Tan, 2004. Sintering behavior of porous SiC ceramics. Ceram. Intl., 30: 869-874.

Cook, S.G., J.A. Little and J.E. King, 1995. Etching and microstructure of engineering ceramics. Mater. Charact., 34: 1-8.

Dasgupta, S. and S.K. Das, 2002. Paper pulp waste-a new source of raw material for the synthesis of a porous ceramic composite. Bull. Mater. Sci., 25: 381-385.

Ding, S., S. Zhu, Y.P. Zeng and D. Jiang, 2007. Fabrication of mullite-bonded porous silicon carbide ceramics by in situ reaction bonding. J. Eur. Ceram. Soc., 27: 2095-2102.

Dittmann, J. and N. Willenbacher, 2014. Micro structural investigations and mechanical properties of macro porous ceramic materials from capillary suspensions. J. Am. Ceram. Soc., 97: 3787-3792.

Dong, Y., S. Hampshire, J.E. Zhou, B. Lin and Z. Ji et al., 2010. Recycling of fly ash for preparing porous mullite membrane supports with titania addition. J. Hazard. Mater., 180: 173-180.
Eom, J.H. and Y.W. Kim, 2009. Effect of additive composition on microstructure and strength of porous silicon carbide ceramics. J. Mater. Sci., 44: 4482-4486.

Eom, J.H. and Y.W. Kim, 2010. Effect of additives on mechanical properties of macroporous silicon carbide ceramics. Met. Mater. Intl., 16: 399-405.

Eom, J.H., Y.W. Kim and S. Raju, 2013. Processing and properties of macroporous silicon carbide ceramics: A review. J. Asian Ceram. Soc., 1: 220-242.

Feng, Y., K. Wang, J. Yao, P.A. Webley and S. Smart et al., 2013. Effect of the addition of polyvinylpyrrolidone as a pore-former on microstructure and mechanical strength of porous alumina ceramics. Ceram. Intl., 39: 7551-7556.

Hou, Z., F. Ye, L. Liu, Q. Liu and H. Zhang, 2013. Effects of solid content on the phase assemblages, mechanical and dielectric properties of porous a-SiAlON ceramics fabricated by freeze casting. Ceram. Intl., 39: 1075-1079.

Hu, L., R. Benitez, S. Basu, I. Karaman and M. Radovic, 2012. Processing and characterization of porous $\mathrm{Ti}_{2}$ AlC with controlled porosity and pore size. Acta Materialia, 60: 6266-6277.

Ighodaro, O.L., O.I. Okoli, M. Zhang and B. Wang, 2012. Ceramic preforms with $2 \mathrm{D}$ regular channels for fabrication of metal/ceramic-reinforced composites. Intl. J. Appl. Ceram. Technol., 9: 421-430.

Jean, G., V. Sciamanna, M. Demuynck, F. Cambier and M. Gonon, 2014. Macroporous ceramics: Novel route using partial sintering of alumina-powder agglomerates obtained by spray-drying. Ceram. Intl., 40: 10197-10203.

Li, G., Y. Fan, Y. Zheng and Y. Wu, 2010. Preparation and properties of high toughness RBAO macroporous membrane support. Ceram. Int., 36: 2025-2031.

Liu, J., Y. Li, Y. Li, S. Sang and S. Li, 2016. Effects of pore structure on thermal conductivity and strength of alumina porous ceramics using carbon black as pore-forming agent. Ceram. Intl., 42: 8221-8228.

Lu, J., L. Gao, J. Sun, L. Gui and J. Guo, 2000. Effect of nickel content on the sintering behavior, mechanical and dielectric properties of $\mathrm{Al}_{2} \mathrm{O}_{3} \mathrm{Ni}$ composites from coated powders. Mater. Sci. Eng. A., 293: 223-228.

Menchavez, R.L. and L.A.S. Intong, 2010. Red clay-based porous ceramic with pores created by yeast-based foaming technique. J. Mater. Sci., 45: 6511-6520.

Mohanta, K., A. Kumar, O. Parkash and D. Kumar, 2014. Processing and properties of low cost macroporous alumina ceramics with tailored porosity and pore size fabricated using rice husk and sucrose. J. Eur. Ceram. Soc., 34: 2401-2412. 
MubarakAli, D., J. Arunkumar, P. Pooja, G. Subramanian, N. Thajuddin and N.S. Alharbi, 2015. Synthesis and characterization of biocompatibility of tenorite nanoparticles and potential property against biofilm formation. Saudi Pharm. J., 23: 421-428.

Norkhairunnisa, M. and K.A. Matori, 2016. Strengthening of porous Alumina Ceramics Using (CU) metal in nanoscale particle and graphite VVaste as a pore agent. J. Eng. Appl. Sci., 100: 2713-2722.

Novais, R.M., M.P. Seabra and J.A. Labrincha, 2014. Ceramic tiles with controlled porosity and low thermal conductivity by using pore-forming agents. Ceram. Intl., 40: 11637-11648.

Ohji, T. and M. Fukushima, 2012. Macro-porous ceramics: Processing and properties. Intl. Mater. Rev., 57: 115-131.

Piazza, D., C. Capiani and C. Galassi, 2005. Piezoceramic material with anisotropic graded porosity. J. Eur. Ceram. Soc., 25: 3075-3078.

Rahmawati, F., N.M. Perkasa, A. Purwanto and M. Nizam, 2014. The performance of $\mathrm{LiFePO}_{4}$ battery with graphite waste as anode material. Proceedings of the 2014 International Conference on Electrical Engineering and Computer Science (ICEECS), November 24-25, 2014, IEEE, Kuta, Indonesia, pp: 209-211.

Ramakrishna, P.V., D.B.R.K. Murthy, D.L. Sastry and K. Samatha, 2014. Synthesis, structural and luminescence properties of $\mathrm{Mn}$ doped $\mathrm{ZnO} / \mathrm{Zn}_{2} \mathrm{SiO}_{4}$ composite microphosphor. Spectrochim. Acta Part A. Mol. Biomol. Spectrosc., 129: 274-279.

Sengphet, K.K.D., K. Pasomsouk, T. Sato, M.A. Fauzi and O. Radzali et al., 2013. Fabrication of porous clay ceramics using kenaf powder waste. Intl. J. Sci. Res. Publ., 3: 1-5.
Shaw, T.M., 1993. Model for the effect of powder packing on the driving force for liquid-phase sintering. J. Am. Ceram. Soc., 76: 664-670.

Shen, L., M. Liu, X. Liu and B. Liu, 2007. Thermal shock resistence of the porous $\mathrm{Al}_{2} \mathrm{O}_{3} / \mathrm{ZrO}_{2}$ ceramics prepared by gelcasting. Mater. Res. Bull., 42: 2048-2056.

Studart, A.R., J. Studer, L. Xu, K. Yoon and H.C. Shum et al., 2010. Hierarchical porous materials made by drying complex suspensions. Langmuir, 27: 955-964.

Studart, A.R., U.T. Gonzenbach, E. Tervoort and L.J. Gauckler, 2006. Processing routes to macroporous ceramics: A review. J. Am. Ceram. Soc., 89: 1771-1789.

Sun, Z., C. Lu, J. Fan and F. Yuan, 2016. Porous silica ceramics with closed-cell structure prepared by inactive hollow spheres for heat insulation. J. Alloys Compd., 662: 157-164.

Wang, S.R., H.R. Geng, L.H. Hui and Y.Z. Wang, 2007. Reticulated porous multiphase ceramics with improved compressive strength and fracture toughness. J. Mater. Eng. Perform., 16: 113-118.

Yin, L., H.X. Peng, S. Dhara, L. Yang and B. Su, 2009. Natural additives in protein coagulation casting process for improved microstructural controllability of cellular ceramics. Composites Part B, 40: 638-644.

Zhao, B., Y. Jiang, B. Yang, T. Wang and Y. Hu et al., 2014. Reactive sintering of tungsten-doped high strength $\mathrm{ZrB}_{2}-\mathrm{SiC}$ porous ceramics using metastable precursors. Mater. Res. Bull., 51: 19-23. 